Sunarya, S. · Murdaningsih H.K. • N. Rostini · Sumadi

\title{
Variabilitas genetik, kemajuan genetik dan pola klaster populasi tegakan benih Paraserianthes falcataria (1.) Nielsen setelah seleksi massa berdasarkan marka morfologi
}

\section{Genetic variability, genetic gain and cluster pattern of Paraserianthes falcataria (1.) Nielsen seed stand population following mass selection base on morphology marker}

Diterima : 15 Februari 2017/Disetujui : 15 Maret 2017 / Dipublikasikan : 30 Maret 2017

CDepartment of Crop Science, Padjadjaran University

\begin{abstract}
Information of Genetic variability, genetic gain and phenotypic cluster pattern are basic investment in tree breeding, which increases the probability to get the superrior character. The aim of this study was to find out some genetic parameters, i.e. genetic variability, genetic gain; and phenotypic cluster pattern, of Paraserianthes falcataria (L.) Nielsen seed stand population following mass selection based on morphology marker. The experiment was arranged in Randomize Complete Block Design with five treatments and four replications.. The experimental material was all individual trees at P. falcataria seed stand. The characters measured were breast height diameter, total height, height clear bole, height crown, branch number, diameter-height ratio and standing stock volume. The result showed that genetic and phenotypic variability based on phenotypic and genetic variance were narrow, and variability based on coefficient varians phenotypic and genetic were low to height. Heritability is low for breast height diameter, height clear bole, and standing stock volume; heritability height for total height,diameter-height ratio,height crown, and branch number. Genetic gain low in standing stock volume; moderat in branch number; and height for breast height diameter, total height, height clear bole, diameter-height ratio and height crown.. Breast height diameter could be used as selection criteria for diameterheight ratio; selection criteria for total height
\end{abstract}

\footnotetext{
Dikomunikasikan oleh Sosiawan Nusifera

Sunarya, S. • Murdaningsih H.K. • N. Rostini • Sumadi2)

1) Kelompok Keahlian Teknologi Kehutanan Program Studi Rekayasa Kehutanan Sekolah Ilmu dan Teknologi Hayati ITB; 2 Fakultas Pertanian - UNPAD).

Korespondensi: sopandies@yahoo.com
}

was height clear bole, height crown, an diameter-height ratio;selection criteria for crown height was branch number and diameter-height ratio.

Key words : Paraserianthes falcataria $\cdot$ Mass selection - Genetic variability - Cluster pattern . Genetic gain $\cdot$ Seed stand $\cdot$ Morphology marker

Sari Informasi variabilitas genetik, kemajuan genetik dan pola kluster fennotipik merupakan dasar pada penelitian pemuliaan pohon yang akan meningkatkan peluang diperolehnya pohon superior. Tujuan penelitian adalah mendapatkan beberapa parameter genetic dan pola kluster dari populasi tegakan benih Paraserianthes falcataria (L.) Nielsen menggunakan seleksi massa berdasarkan marker morfologi. Percobaan disusun menggunakan Rancangan Acak Kelompok (RBD) dengan lima perlakuan yang diulang empat kali. Materi percobaan adalah individu pohon pada tegakan benih $P$. falcataria. Pengamatan dilakukan terhadap karakter diameter setinggi dada (DBH), tinggi total (Ttot), tinggi bebas cabang (Tbc), kekekaran pohon (KPhn), tinggi tajuk (Ttjk), jumlah cabang (JCbg) dan volume pohon (VPhn). Variabilitas genetik dan fenotipik berdasarkan varians adalah sempit dan variabilitas sempit sampai luas berdasarkan koefisien variasi genetik dan fenotipik. Heritabilitas rendah pada diameter setinggi dada, tinggi bebas cabang dan volume standing stock, heritabilitas tinggi pada tinggi total, kekekaran pohon (rasio diameter-tinggi), tinggi tajuk dan jumlah cabang. Kemajuan genetik rendah pada volume standing stock, kemajuan genetik sedang pada jumlah cabang, kemajuan genetik tinggi pada karakter diameter 
detinggi dada, tinggi total, tinggi bebas cabang, kekekaran pohon dan tinggi tajuk. Kriteria seleksi pada karakter volume standing stock adalah diameter setinggi dada dan tinggi bebas cabang, kriteria seleksi tinggi total adalah tinggi bebas cabang, tinggi tajuk, jumlah cabang dan kekekaran pohon, kriteria seleksi untuk tinggi tajuk adalah jumlah cabang dan kekekaran pohon.

Key words : Paraserianthes falcataria $\cdot$ Seleksi massa - Variabilitas genetik - Pola kluster . Kemajuan genetik - Tegakan benih $\cdot$ Marker morfologi

\section{Pendahuluan}

Variabilitas genetik, kemajuan genetik dan pola klaster merupakan modal dasar dalam pemuliaan pohon karena melalui variabilitas genetik peluang untuk memperoleh karakter unggul akan semakin tinggi. Dengan demikian, varibilitas genetik menjadi salah satu indikator dalam mencapai keberhasilan program pemuliaan. Brown, et al. (1987) cit. Van Beuningen (1997), studi dan informasi mengenai tingkat variabilitas genetik sangat diperlukan oleh pemulia dalam mengidentifikasi calon tetua persilangan yang potensial. Disamping itu, akan bermanfaat pula guna mencegah penggunaan tetua-tetua berkerabat dekat. Bermanfaat dalam mendukung program pemuliaan apabila telah diidentifikasi karakter-karakter penting.

Variabilitas suatu fenotipe tanaman dalam populasi pada suatu sistem biologi dapat disebabkan oleh : variabilitas genetik penyusun populasi, keragaman lingkungan dan keragaman interaksi genotipe dan lingkungan. Keragaman fenotipe suatu karakter tanaman yang disebabkan peranan faktor genetik, maka variabilitas tersebut akan dapat diwariskan pada generasi selanjutnya. Oleh karena itu, pada tanaman yang diperbanyak melalui biji segregasi gen dari generasi ke generasi akan menyebabkan meningkatnya variabilitas genetik (Allard, 1992).

Aktivitas pemuliaan berupa seleksi pada suatu populasi harus dievaluasi hasilnya agar dapat diperoleh informasi sejauhmana keberhasilan program pemuliaan tersebut serta dapat dijadikan landasan untuk program pemuliaan selanjutnya. Efektivitas dan efisiensi seleksi menjadi indikator dalam proses pemu- liaan suatu populasi (khususnya manajemen sumber benih $P$. falcataria) yang ditujukan untuk menyediakan benih-benih bermaterial genetik unggul. Keberhasilan suatu program pemuliaan tanaman sangat bergantung pada variasi genetik yang diturunkan/diwariskan. Karena tanpa variasi genetik tidak akan terjadi perbaikan sifat tanaman (Poehlman dan Sleper, 1995). Oleh karenanya, informasi mengenai besarnya nilai pendugaan parameter (varians genetik, varians fenotipik, heritabilitas dan kemajuan genetik) untuk berbagai sifat tanaman sangat diperlukan dalam program pemuliaan untuk memperoleh kultivar yang diharapkan (Murdaningsih, et al., 1990).

Nilai estimasi heritabilitas dapat memberikan petunjuk sederhana terhadap besar kecilnya pengaruh genetik dan lingkungan dari suatu populasi (Dudley dan Moll, 1969; Poespodarsono, 1988; Allard, 1992), sehingga apabila nilai estimasi heritabilitas digabungkan dengan nilai kemajuan genetik dari seleksi, maka akan lebih bermanfaat dalam meramalkan hasil akhir untuk melakukan seleksi sifat individu yang baik (Dudley dan Moll, 1969). Penelitian ini bertujuan mempelajari variabilitas genetik, kemajuan genetik dan pola klaster populasi tegakan benih $P$. falcataria setelah dilakukan aktivitas seleksi massa terhadap karakter morfologi sebagai dasar keberhasilan program pemuliaan pohon maupun strategi pemuliaan selanjutnya.

\section{Bahan dan Metode}

Percobaan dilakukan dari Januari 2010 sampai Maret 2010 di tegakan benih P. falcataria ITB Kampus Jatinangor, Jawa Barat, Indonesia. Obyek penelitian adalah tegakan benih $P$. falcataria yang dibangun pada akhir tahun 1999 atau awal tahun 2000 dengan rancangan lapangan Rancangan Acak Kelompok (RBD). Seleksi massa (mass selection) dilakukan dengan frekuensi 2 kali pada tahun 1997 dan tahun 2009 dengan cara mengeliminasi individu-individu yang terserang boktor.

Karakter-karater yang diamati berdasarkan P. falcataria sebagai kayu pertukangan, yaitu : diameter setinggi dada (DBH), tinggi total (Ttot), tinggi bebas cabang (Tbc), kekekaran pohon (KPhn), tinggi tajuk (Ttjk), jumlah cabang (JCbg) dan volume pohon (VPhn). Variabilitas genetik dianalisis melalui metode komponen varians 
dengan perlakuan Provenan (5) dan ulangan (4). Model linier aditif mengacu (Mattjik dan Sumertajaya, 2002). Pendugaan komponen ragam genetik dan fenotipik mengacu (Anderson dan Bancroft, 1952 cit. Daradjat, 1987). Kriteria penilaian terhadap luas atau sempitnya variabilitas fenotipik dan genetik mengacu Pinaria (1995).

Nilai koefisien variasi genetik (KVG) dan varians fenotipik (KVF) dihitung menurut rumus (Singh and Chaudary, 1979). Koefisien variasi genetik dan fenotipik diklasifikasikan menurut (Miligan et al., 1996 dikutip Sudarmadji et al., 2007) sebagai berikut : luas (jika nilainya $\geq$ $14,5 \%$ ), sedang (jika nilainya antara $5 \%$ sampai < $14,5 \%$ ), sempit (jika nilainya $<5 \%$ ). Nilai duga heritabilitas arti luas dihitung menurut (Singh dan Chaudary, 1977) dengan menggunakan rumus : $\mathrm{H}=\sigma^{2} \mathrm{~g} / \sigma^{2}$ f. Klasifikasi heritabillitas mengacu (Stansfield, 1991). Nilai kemajuan genetik (KG) dihitung berdasarkan metode yang dikemukakan oleh Singh and Chaudhary (1979). Kriteria KG mengacu kepada Begum dan Sobhan (1991) dalam Rostini, et. al. (2006), yaitu : KG > 15\% : besar, KG antara 7\% - 14\% : sedang dan jika $\mathrm{KG}<7 \%$ : rendah. Korelasi genetik dan fenotipik mengacu (Singh dan Chaudary, 1977). Analisis klaster yang menggambarkan kekerabatan masing-masing provenan pada populasi tegakan benih menggunakan analisis multivariate Principle Component Analisys (PCA) berdasarkan Gasperz (1995).

\section{Hasil dan Pembahasan}

Aktivitas pemuliaan berupa seleksi massa pada tegakan benih $P$. falcataria. berakibat terhadap menurunnya variabilitas genetik. Penurunan variabilitas genetik ditunjukkan oleh sempitnya variasi genetik dan fenotipik (Pinaria. 1995) untuk semua karakter yang dianalisis. Variasi genetik dan fenotipik yang sempit dicirikan oleh nilai variasi fenotipik yang berkisar antara 0.002 pada karakter volume pohon (VPhn) sampai 2.870 pada karakter diameter setinggi dada (DBH). Nilai variasi genetik berkisar antara 0.000 pada karakter volume pohon (VPhn) sampai 1.599 pada karakter tinggi total (Ttot) (Tabel 1.). Nilai variasi fenotipik semua karakter menunjukkan selalu lebih tinggi dibandingkan variasi genetik seperti Gambar 1.

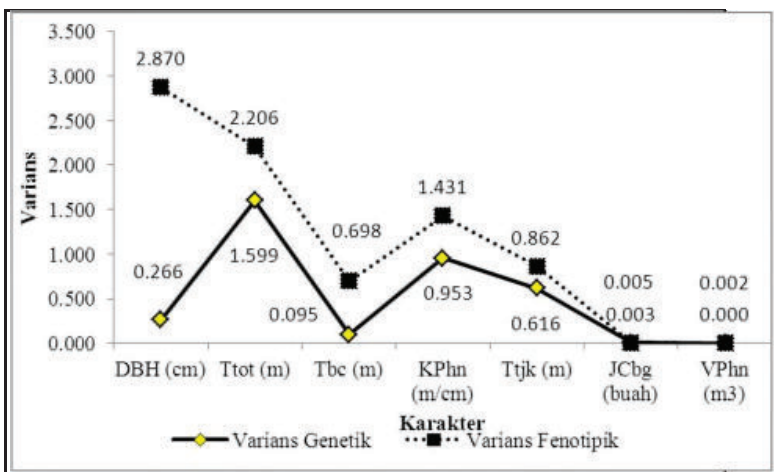

Gambar 1. Perbandingan varians fenotipik dan genetik populasi tegakan benih $P$. falcataria setelah seleksi

Nilai variasi fenotipik yang lebih tinggi dibandingkan nilai variasi genetik, mengindikasikan bahwa semua karakter yang dianalisis lebih cenderung dikendalikan faktor lingkungan maupun faktor interaksi genetik dan lingkungan. Karakter-karakter yang dianalisis merupakan karakter kuantitatif yang dikendali-

Tabel 1. Nilai parameter genetik populasi tegakan benih $P$. falcataria setelah seleksi

\begin{tabular}{|c|c|c|c|c|c|c|c|c|c|c|c|c|c|}
\hline \multirow{2}{*}{$\begin{array}{l}\text { No } \\
1\end{array}$} & \multirow{2}{*}{$\begin{array}{c}\text { Karakter } \\
\mathrm{DBH}(\mathrm{cm})\end{array}$} & \multicolumn{2}{|c|}{ KVG (\%) } & \multicolumn{2}{|c|}{$\begin{array}{l}\text { Varians } \\
\text { Genetik }\end{array}$} & \multicolumn{2}{|c|}{ KVF (\%) } & \multicolumn{2}{|c|}{$\begin{array}{l}\text { Varians } \\
\text { Fenotipik }\end{array}$} & \multicolumn{2}{|l|}{$\mathbf{H}$} & \multicolumn{2}{|l|}{ KG (\%) } \\
\hline & & 1.86 & K & 0.266 & $S$ & 6.11 & $S$ & 2.870 & $S$ & 0.093 & $\mathrm{r}$ & 32.29 & B \\
\hline 2 & Ttot $(\mathrm{m})$ & 8.53 & S & 1.599 & $S$ & 10.02 & $S$ & 2.206 & $S$ & 0.725 & $\mathrm{t}$ & 221.81 & B \\
\hline 3 & $\mathrm{Tbc}(\mathrm{m})$ & 3.72 & K & 0.095 & $S$ & 10.10 & $S$ & 0.698 & $S$ & 0.136 & $r$ & 23.38 & B \\
\hline 4 & $\begin{array}{l}\text { KPhn } \\
(\mathrm{m} / \mathrm{cm})\end{array}$ & 14.86 & B & 0.953 & $S$ & 18.21 & B & 1.431 & $S$ & 0.666 & $t$ & 164.11 & B \\
\hline 5 & Ttjk (m) & 10.10 & S & 0.616 & S & 11.95 & S & 0.862 & $S$ & 0.715 & $\mathrm{t}$ & 136.72 & B \\
\hline 6 & JCbg (buah) & 10.15 & $S$ & 0.003 & $S$ & 12.42 & $S$ & 0.005 & $S$ & 0.668 & $\mathrm{t}$ & 9.27 & $S$ \\
\hline 7 & $\operatorname{VPhn}\left(\mathrm{m}^{3}\right)$ & 0.85 & K & 0.000 & $S$ & 17.49 & B & 0.002 & $S$ & 0.002 & r & 0.02 & K \\
\hline
\end{tabular}

Keterangan : KVG = koefisien variasi genetik; KVF = keofisien varians fenotipik; KG = kemajuan genetik $(\mathrm{K}=$ kecil. $\mathrm{S}=$ sedang. $\mathrm{B}=$ besar $) ; \mathrm{S}=$ sempit; $\mathrm{L}=$ luas; $\mathrm{r}=$ rendah; $\mathrm{s}=$ sedang; $\mathrm{t}=$ tinggi; $\mathrm{H}=$ heritabilitas; $\mathrm{DBH}=$ diameter setinggi dada; Ttot=tinggi total; $\mathrm{Tbc}=$ tinggi bebas cabang; $\mathrm{KPhn}=$ kekekaran pohon; Ttjk=tinggi tajuk; JCbg=jumlah cabang; VPhn=volume pohon 
kan oleh banyak gen (polygenic) yang sangat peka terhadap lingkungan (Falconer dan Mackay, 1996). Menurunnya variasi genetik populasi tegakan benih akibat mass selection, mengindikasikan telah terjadinya efek seleksi negatif (dysgenic selection) pada populasi tersebut (Rostini, dkk., 2008; Hardiyanto, 2000). Pada kondisi populasi demikian, maka seleksi famili menjadi metode yang disarankan karena pada kondisi populasi dengan variasi yang rendah seleksi tidak dapat memperoleh hasil atau tujuan yang dinginkan (Hardiyanto, 2000).

Populasi tegakan benih $P$. falcataria setelah seleksi memiliki nilai KVG yang cenderung lebih tinggi dibandingkan KVF. Nilai koefisien variasi genetik berkisar antara $0.85 \%$ pada karakter volume pohon (VPhn) sampai $14.86 \%$ pada karakter kekekaran pohon (KPhn). Karakter kekekaran pohon (KPhn) merupakan karakter dengan variabilitas genetik luas karena nilai KVG terklasifikasi besar (Miligan. et al.. 1996 dikutip Sudarmadji. et al.. 2007). Sebaliknya, nilai KVF berkisar antara 6.11\% pada karakter diameter setinggi dada (DBH) sampai $18.21 \%$ pada karakter kekekaran pohon (KPhn). Berdasarkan nilai KVF terlihat 2 (dua) karakter dengan variabilitas genetik luas. yaitu : karakter kekekaran pohon (KPhn) dan karakter volume pohon (VPhn).

Nilai estimasi heritabilitas dapat memberikan petunjuk sederhana terhadap besar kecilnya pengaruh genetik dan lingkungan dari suatu populasi (Dudley dan Moll, 1969; Poespodarsono, 1988; Allard, 1992). Estimasi heritabilitas tergolong rendah sampai tinggi (Stansfield, 1991). Karakter volume pohon (VPhn) memiliki nilai estimasi heritabilitas paling rendah sebesar 0.002 dan karakter tinggi total (Ttot) memiliki nilai estimasi heritabilitas paling tinggi sebesar 0.725. Karakter-karakter dengan nilai estimasi heritabilitas tinggi yang mengindikasikan faktor genetik lebih dominan dibandingkan faktor lingkungan terdapat pada karakter-karakter : tinggi total (Ttot) 0.725, kekekaran pohon (KPhn) 0.666, tinggi tajuk (Ttjk) 0.715 dan jumlah cabang 0.668. Kemajuan genetik memperlihatkan nilai yang bervariasi dari $0.002 \%$ pada karakter volume pohon (VPhn) sampai $221.81 \%$ pada karakter tinggi total (Ttot). Adanya seleksi pada populasi tegakan benih $P$. falcataria ternyata telah dapat meningkatkan kemajuan genetik, terutama untuk karakter : diameter setinggi dada (DBH) $32.29 \%$, tinggi total (Ttot) $221.81 \%$, tinggi bebas cabang (Tbc) 23.38\%, kekekaran pohon (KPhn) $164.10 \%$ dan tinggi tajuk (Ttjk) $136.71 \%$.

Sebagai landasan seleksi. populasi tegakan benih dapat diseleksi saat ini karena terdapat beberapa karakter dengan variabilitas fenotipik dan genetik yang luas. Seleksi akan cukup efektif apabila dilakukan pada karakter kekekaran pohon (KPhn), tinggi total (Ttot), tinggi tajuk (Ttjk) dan jumlah cabang (JCbg). Sementara itu. pada karakter-karakter lainnya, seperti : diameter setinggi dada (DBH), tinggi bebas cabang (Tbc) dan volume pohon (VPhn) seleksi akan lebih efektif apabila dilakukan pada generasi berikutnya. .

Hasil analisis korelasi fenotipik dan genetik populasi tegakan benih $P$. falcataria setelah seleksi sebagaimana Tabel 2. Karakter dengan nilai koefisien korelasi paling tinggi antara tinggi total (Ttot) dengan kekekaran pohon (KPhn) sebesar 0.89. Karakter diameter setinggi dada juga memiliki nilai korelasi yang erat dengan karakter-karakter : tinggi bebas cabang (Tbc), tinggi tajuk (Ttjk), jumlah cabang (JCbg) dan kekekaran pohon (KPhn). Keeratan antar karakter tersebut dikarenakan volume merupakan kuadrat dari diameter sebagaimana dikemukakan oleh (Chapman and Meyer, 1949; Laar and Akca, 1997), bahwa diameter merupakan variabel yang praktis untuk menduga volume. Disamping itu, dipengaruhi pula oleh proses fisiologi tanaman. Misalnya, semakin besar diameter batang maka suplai air, nutrien dan mineral akan semakin tinggi untuk proses fotosintesis dan juga kemampuan distribusi asimilat akan semakin besar. Tingginya distribusi asimilat akan memacu pertumbuhan tinggi total (Ttot), tinggi bebas cabang (Tbc), tinggi tajuk (Ttjk) dan akhirnya volume pohon (VPhn) (Daniel, et al., 1992; Loveless, 1987; Lakitan, 2004; Salisbury dan Ross, 1995).

Tujuan seleksi terhadap orientasi pemuliaan Sengon lebih difokuskan terhadap karakter pertumbuhan, yaitu : diameter setinggi dada (DBH), tinggi total (Ttot), tinggi bebas cabang (Tbc) dan tinggi tajuk (Ttjk). Hal ini dikarenakan tujuan pemuliaan Sengon lebih ditekankan kepada bagaimana memperoleh $P$. falcataria dengan volume yang tinggi. Variabel yang dijadikan dasar untuk pengukuran volume adalah dimeter batang dan tinggi bebas cabang dan karakter volume batang kayu merupakan karakter kuantitatif dan memiliki nilai ekonomis tinggi. Selanjutnya, Lamb and Borschmann 
Tabel 2. Matriks pola korelasi fenotipik dan genetik populasi tegakan benih $P$. falcataria setelah seleksi

\begin{tabular}{|c|c|c|c|c|c|c|c|c|c|c|c|c|}
\hline \multirow{2}{*}{ Karakter } & \multicolumn{2}{|c|}{ DBH } & \multicolumn{2}{|c|}{ Ttot } & \multicolumn{2}{|c|}{ Tbc } & \multicolumn{2}{|c|}{ Ttjk } & \multicolumn{2}{|c|}{$\mathrm{JCbg}$} & \multicolumn{2}{|c|}{ KPhn } \\
\hline & $\mathbf{r}_{\mathrm{f}}$ & $r_{g}$ & $\mathbf{r}_{\mathrm{f}}$ & $\mathbf{r}_{\mathrm{g}}$ & $\mathbf{r}_{\mathrm{f}}$ & $r_{g}$ & $\mathbf{r}_{\mathrm{f}}$ & $r_{g}$ & $r_{f}$ & $r_{g}$ & $\mathbf{r}_{\mathrm{f}}$ & $r_{g}$ \\
\hline Ttot & $-0.05 \mathrm{tn}$ & $-0.40 \mathrm{tn}$ & & & & & & & & & & \\
\hline Tbc & 0.41 tn & $-0.06 \mathrm{tn}$ & $0.58^{*}$ & $0.42 \mathrm{tn}$ & & & & & & & & \\
\hline Ttjk & $-0.37 \mathrm{tn}$ & $-0.48 \mathrm{tn}$ & $0.78^{*}$ & $0.69^{*}$ & $-0.06 \mathrm{tn}$ & $0.39 \mathrm{tn}$ & & & & & & \\
\hline $\mathrm{JCbg}$ & $0.41 \mathrm{tn}$ & $0.62^{*}$ & $-0.50^{*}$ & $-0.46 \mathrm{tn}$ & $0.05 \mathrm{tn}$ & $0.03 \mathrm{tn}$ & $-0.66^{*}$ & $-0.60^{*}$ & & & & \\
\hline KPhn & $-0.49 \mathrm{tn}$ & $-0.44 \mathrm{tn}$ & $0.89^{*}$ & $0.69^{*}$ & $0.32 \mathrm{tn}$ & 0.38 th & $0.85^{*}$ & $0.71^{*}$ & $-0.63^{*}$ & $-0.55^{*}$ & & \\
\hline VPhn & $0.82^{*}$ & $0.08 \mathrm{tn}$ & $0.34 \mathrm{th}$ & $0.17 \mathrm{tn}$ & $0.85^{*}$ & $0.10 \mathrm{tn}$ & $-0.24 \mathrm{tn}$ & $-0.03 \mathrm{tn}$ & $0.27 \mathrm{tn}$ & $0.42 \mathrm{tn}$ & $-0.08 \mathrm{tn}$ & $0.00 \mathrm{tn}$ \\
\hline
\end{tabular}

Keterangan : $\mathrm{r}_{\mathrm{f}}=$ korelasi fenotipik; $\mathrm{r}_{\mathrm{g}}=$ korelasi genetik; $\mathrm{tn}=$ tidak nyata; ${ }^{*}=$ beda nyata pada taraf $5 \%$; $\mathrm{DBH}=$ diameter setinggi dada; Ttot=tinggi total; Tbc=tinggi bebas cabang; Ttjk=tinggi tajuk; JCbg=jumlah cabang; KPhn=kekekaran pohon

(1998), menyatakan juga bahwa volume bebas cabang sering digunakan dalam menduga volume kayu pertukangan.

Falconer dan Mackay (1996) menyatakan bahwa prasyarat utama agar seleksi tidak langsung dapat dilakukan adalah adanya korelasi genetik antara karakter yang dituju dan karakter sekunder yang diseleksi. Pada kondisi dimana karakter-karakter berkorelasi secara genetik namun tidak berkorelasi secara fenotipik, seleksi tidak langsung tidak dapat dilakukan. Dengan demikian, karakter yang berpotensi sebagai kriteria seleksi pada karakter volume standing stock (VPhn) adalah diameter setinggi dada $(\mathrm{DBH})$ dan tinggi bebas cabang (Tbc); kriteris seleksi tinggi total (Ttot) adalah tinggi bebas cabang (Tbc), tinggi tajuk (Ttjk), jumlah cabang (JCbg) dan kekekaran pohon (KPhn); kriteria seleksi untuk tinggi tajuk (Ttjk) adalah jumlah cabang (JCbg) dan kekekaran pohon (KPhn).

Secara umum, terlihat bahwa secara genetik semua karakter berkorelasi dengan dua atau lebih karakter lainnya. Hal ini dikarenakan oleh karakter yang diamati merupakan karakter kuantitatif. Dengan asumsi bahwa karakter kuantitatif benar dikendalikan oleh polygenic, maka wajar apabila karakter-karakter tersebut lebih berkorelasi secara genetik daripada secara fenotipik. Nusifera (2012), hal ini dikarenakan efek pleiotropy ataupun linkage pada gen-gen tertentu tidak selalu berdampak sama pada penampilan suatu karakter. Oleh karena itu, dua karakter yang berkorelasi secara genetik belum tentu berkorelasi secara fenotipik.

Dampak seleksi terhadap populasi dapat pula dianalisis berdasarkan pola pengelompokkan yang dialakukan berdasarkan analisis komponen utama atau PCA (principal component analysis). Melalui analisis komponen utama ini dapat tergambarkan pola klaster dari masing- masing populasi yang mengindikasikan pola hubungan kekerabatan. Hasil analisis komponen utama populasi tegakan benih setelah seleksi disajikan pada Tabel 3.

Signifikansi komponen utama populasi tegakan benih setelah seleksi yang ditunjukkan oleh nilai akar ciri/ragam lebih dari 1 terdapat pada komponen utama 1 dan 2. Proporsi variasi yang dapat dijelaskan pada kedua komponen utama tersebut yang ditunjukkan oleh nilai keragaman kumulatif sebesar 83.20\%. Hal ini bermakna bahwa variasi total dari 7 variabel yang dianalisis dapat dijelaskan melalui variasi dua variabel komponen utama. Variasi yang ada pada tiap komponen utama dideterminasi oleh karakter-karakter tertentu yang umumnya berbeda antara komponen utamanya. kecuali pada karakter dimeter setinggi dada (DBH) dan tinggi total (Ttot). Kedua karakter tersebut dapat mendiskriminasi baik pada komponen utama pertama maupun komponen utama kedua. Karakter-karakter yang mendiskriminasi variasi pada komponen utama pertama adalah : diameter setinggi dada (DBH), tinggi total (Ttot), tinggi tajuk (Ttjk), jumlah cabang (JCbg) dan kekekaran pohon (KPhn). Sementara itu, pada komponen utama kedua karakter-karakter yang mendiskriminasi variasi adalah : diameter setinggi dada (DBH), tinggi total (Ttot), tinggi bebas cabang (Tbc) dan volume pohon (VPhn).

Efek karakter terhadap diskriminasi variasi dapat dilihat juga berdasarkan koefisien skor komponen utama (KSK). Dimana semakin tinggi koefisien skor komponen utama (KSK), semakin tinggi juga variasi yang ditimbulkan oleh karakter tersebut. Koefisien skor komponen utama (KSK) pada karakter kekekaran pohon (KPhn) memiliki nilai tertinggi, yaitu : 0.28. Oleh karena itu. karakter kekekaran pohon merupakan karakter yang paling tinggi berefek terhadap diskriminasi variasi. Sebaliknya, pada 
karakter tinggi bebas cabang (Tbc) dengan nilai koefisien skor komponen utama (KSK) sebesar 0.03 memberikan efek paling rendah terhadap diskriminasi variasi populasi tegakan benih. Karakter-karakter yang memiliki efek menurunkan variasi terlihat dengan nilai koefisien skor komponen utama negatif yang terjadi pada karakter-karakter : diameter setinggi dada (DBH) sebesar -0.19, jumlah cabang (JCbg) sebesar -0.23 dan volume pohon (VPhn) sebesar -0.11. Berdasarkan nilai skor komponen utama, populasi tegakan benih setelah seleksi dapat dikategorikan rendah pada karakter jumlah cabang (JCbg) sampai sedang pada karakter-karakter lainnya. Urutan masingmasing karakter berdasarkan diskriminasi variasi populasi tegakan benih setelah seleksi masing-masing adalah : 1). Kekekaran pohon (KPhn). 2). Tinggi tajuk (Ttjk), 3). Tinggi total (Ttot), 4). Tinggi bebas cabang (Tbc), 5). Volume pohon (VPhn), 6). Diameter setinggi dada (DBH), dan 7). Jumlah cabang (JCbg). Semakin kecil rangking dari suatu karakter, semakin besar karakter tersebut beprpengaruh terhadap diskriminasi variasi (Gasperz, 1995).

Pola variasi masing-masing provenan pada tegakan benih berdasarkan skor komponen utama dapat diinterpretasi pula melalui grafik bi-plot sebagaimana tersaji pada Gambar 2 yang memperlihatkan pola kekerabatan provenan berdasarkan skor komponen utama pertama dan kedua.

Pengelompokan Provenan Kuningan pada kuadran IV dan tidak memiliki kemiripan dengan provenan lainnya. disebabkan oleh karakter diameter setinggi dada (DBH) dan karakter volume pohon (VPhn) dengan nilai rata-rata paling tinggi dibandingkan provenan lainnya. Pola kemiripan Provenan Banjarnegara dengan Provenan Solomon pada kuadran I disebabkan oleh karakter : tinggi bebas cabang (Tbc), kekekaran pohon (KPhn), tinggi tajuk (Ttjk) dan volume pohon (VPhn). Karakterkarakter tersebut memiliki nilai rata-rata yang hampir sama (Tabel 4.), sehingga pola kemiripan karakter tersebut menjadi tinggi. Pola kemiripan

Tabel 3. Skor komponen utama, koefisien skor komponen utama dan pengelompokkan karakter fenotipik tegakan benih uji provenan $P$. falcataria setelah seleksi

\begin{tabular}{|c|c|c|c|c|c|c|c|c|c|c|c|c|c|c|c|}
\hline \multirow{2}{*}{ No } & \multirow{2}{*}{ Karakter } & \multicolumn{12}{|c|}{ Komponen Utama (PC) } & \multirow[b]{2}{*}{ - KSK } & \multirow[b]{2}{*}{$\mathbf{P}$} \\
\hline & & 1 & 2 & 3 & 4 & 5 & 6 & 7 & 8 & 9 & 10 & 11 & 12 & & \\
\hline 1 & $\mathrm{DBH}(\mathrm{cm})$ & -0.35 & -0.38 & -0.59 & 0.03 & -0.31 & -0.18 & 0.51 & - & - & - & - & - & -0.19 & $S$ \\
\hline 2 & Ttot $(\mathrm{m})$ & 0.42 & -0.39 & -0.08 & -0.24 & 0.46 & -0.63 & -0.01 & - & - & - & - & - & 0.23 & $S$ \\
\hline 3 & $\mathrm{Tbc}(\mathrm{m})$ & 0.05 & -0.58 & 0.50 & 0.15 & 0.20 & 0.41 & 0.43 & - & - & - & - & - & 0.03 & $S$ \\
\hline 4 & Ttjk (m) & 0.47 & -0.03 & -0.52 & -0.35 & 0.11 & 0.61 & 0.00 & - & - & - & - & - & 0.25 & $S$ \\
\hline 5 & JCbg (buah) & -0.42 & -0.04 & 0.24 & -0.87 & -0.04 & 0.03 & 0.01 & - & - & - & - & - & -0.23 & $\mathrm{R}$ \\
\hline 6 & $\operatorname{KPhn}(\mathrm{m} / \mathrm{cm})$ & 0.52 & -0.12 & 0.25 & -0.14 & -0.79 & -0.13 & 0.03 & - & - & - & - & - & 0.28 & $S$ \\
\hline 7 & VPhn $\left(\mathrm{m}^{3}\right)$ & -0.20 & -0.59 & -0.10 & 0.10 & -0.14 & 0.12 & -0.74 & - & - & - & - & - & -0.11 & $S$ \\
\hline \multirow{2}{*}{\multicolumn{2}{|c|}{$\begin{array}{l}\text { Rata-rata } \\
\text { Standar deviasi }\end{array}$}} & 0.07 & 0.30 & 0.04 & 0.19 & 0.07 & 0.03 & 0.03 & - & - & - & - & - & 0.04 & - \\
\hline Stan & & 0.40 & 0.24 & 0.41 & 0.35 & 0.40 & 0.41 & 0.41 & - & - & - & - & - & 0.22 & - \\
\hline
\end{tabular}

Keterangan : $\mathrm{DBH}=$ diameter setinggi dada; Ttot=tinggi total; Tbc=tinggi bebas cabang; Ttjk=tinggi tajuk; JCbg=jumlah cabang; KPhn=kekekaran pohon

Tabel 4. Nilai rata-rata karakter masing-masing provenan populasi tegakan benih $P$. falcataria setelah seleksi

\begin{tabular}{crccccc}
\hline \hline \multirow{2}{*}{ No } & \multirow{2}{*}{ Karakter } & \multicolumn{5}{c}{ Provenan (Rata $^{2}$ ) } \\
\cline { 3 - 6 } & & Subang & Kediri & Solomon & Banjarnegara $_{c}$ Kuningan \\
\hline 1 & DBH $(\mathrm{cm})$ & $28.46 \mathrm{ab}$ & $27.90 \mathrm{ab}$ & $26.57 \mathrm{a}$ & $27.48 \mathrm{ab}$ & $28.90 \mathrm{~b}$ \\
2 & Ttot $(\mathrm{m})$ & $13.04 \mathrm{a}$ & $13.97 \mathrm{ab}$ & $14.88 \mathrm{~b}$ & $16.29 \mathrm{c}$ & $15.94 \mathrm{c}$ \\
3 & Tbc $(\mathrm{m})$ & $8.25 \mathrm{ab}$ & $7.47 \mathrm{a}$ & $8.53 \mathrm{~b}$ & $8.85 \mathrm{~b}$ & $8.98 \mathrm{~b}$ \\
4 & KPhn $(\mathrm{m} / \mathrm{cm})$ & $0.46 \mathrm{a}$ & $0.51 \mathrm{ab}$ & $0.57 \mathrm{~b}$ & $0.60 \mathrm{~b}$ & $0.56 \mathrm{~b}$ \\
5 & Ttjk $(\mathrm{m})$ & $4.79 \mathrm{a}$ & $6.50 \mathrm{~b}$ & $6.43 \mathrm{~b}$ & $7.44 \mathrm{~b}$ & $6.96 \mathrm{~b}$ \\
6 & JCbg $(\mathrm{buah})$ & $8.82 \mathrm{~b}$ & $7.46 \mathrm{ab}$ & $7.24 \mathrm{ab}$ & $7.18 \mathrm{a}$ & $8.20 \mathrm{~b}$ \\
7 & VPhn $\left(\mathrm{m}^{3}\right)$ & $0.29 \mathrm{ab}$ & $0.26 \mathrm{a}$ & $0.26 \mathrm{a}$ & $0.29 \mathrm{ab}$ & $0.33 \mathrm{~b}$ \\
\hline \hline
\end{tabular}

Keterangan : DBH=diameter setinggi dada; Ttot=tinggi total; Tbc=tinggi bebas cabang; Ttjk=tinggi tajuk; $\mathrm{JCbg}=$ jumlah cabang; $\mathrm{KPhn}=$ kekekaran pohon; angka yang diikuti huruf yang sama tidak berbeda nyata pada $\mathrm{a}=5 \%$ berdasarkan uji lanjut Duncan 


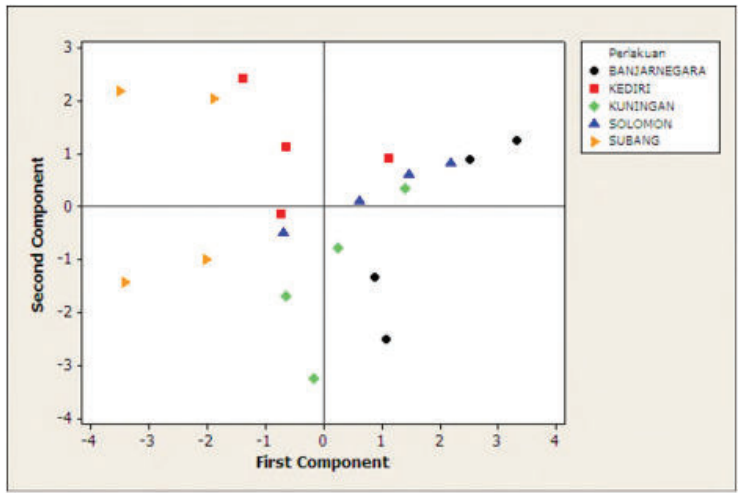

Gambar 2. Pola pengelompokan masing-masing provenan pada tegakan benih $P$. falcataria setelah seleksi berdasarkan komponen utama 1 dan 2

yang sama antara Provenan Subang dan Provenan Kediri pada kuadran II dipengaruhi oleh karakter-karakter dengan nilai rata-rata yang hampir sama atau homogen. Karakterkarakter tersebut adalah : diameter setinggi dada (DBH), tinggi total (Ttot), tinggi bebas cabang (Tbc), kekekaran pohon (KPhn), jumlah cabang (JCbg) dan volume pohon (VPhn). Selanjutnya, pola kemiripan antara Provenan Kuningan dan Provenan Subang pada kuadran III disebabkan oleh karakter-karakter : diameter setinggi dada $(\mathrm{DBH})$, tinggi bebas cabang (Tbc), jumlah cabang (JCbg) dan volume pohon (VPhn).

Introduksi Provenan Solomon pada tegakan benih $P$. falcataria, ternyata belum dapat meningkatkan variabilitas genetik tegakan benih tersebut. Hal ini ditunjukkan oleh kemiripan yang sama dengan Provenan Kediri, Banjarnegara dan Provenan Kuningan. Karakterkarakter yang berpengaruh terhadap kemiripan ketiga provenan tersebut adalah : tinggi bebas cabang (Tbc), kekekaran pohon (KPhn) dan tinggi tajuk (Ttjk). Hal ini menunjukkan bahwa masing-masing provenan memiliki kekerabatan yang dekat (variabilitas genetik rendah) yang diduga akibat penyebaran sengon memiliki genetic base yang sempit. Heyne (1987), di Pulau Banda sengon ditemukan oleh Teysman dan dibawa ke Kebun Raya Bogor, dari Kebun Raya ini sejak 1871 tersebar di seluruh Nusantara. Disamping itu, Finkeldey (2005) mengemukakan juga bahwa faktor yang menurunkan keragaman genetik adalah seleksi serta genetic drift (penghanyutan genetik).

\section{Kesimpulan}

Variabilitas genetik dan fenotipik berdasarkan varians adalah sempit dan variabilitas sempit sampai luas berdasarkan koefisien variasi genetik dan fenotipik. Heritabilitas rendah pada diameter setinggi dada, tinggi bebas cabang dan volume standing stock, heritabilitas tinggi pada tinggi total, kekekaran pohon (rasio diametertinggi), tinggi tajuk dan jumlah cabang. Kemajuan genetik kecil pada volume standing stock, kemajuan genetik sedang pada jumlah cabang, kemajuan genetik besar pada karakter diameter detinggi dada, tinggi total, tinggi bebas cabang, kekekaran pohon dan tinggi tajuk.

Kriteria seleksi pada karakter volume standing stock adalah diameter setinggi dada dan tinggi bebas cabang, kriteria seleksi tinggi total adalah tinggi bebas cabang, tinggi tajuk, jumlah cabang dan kekekaran pohon, kriteria seleksi untuk tinggi tajuk adalah jumlah cabang dan kekekaran pohon. Seleksi pada salah satu karakter tersebut dapat meningkatkan karakter lainnya.

Provenan Solomon memiliki kekerabatan yang dekat dengan Provenan Kuningan, Kediri dan Subang dan persilangan antar provenan belum dapat meningkatkan variabilitas genetik populasi tegakan benih $P$. falcataria.

\section{Ucapan Terıma Kasih}

Ucapan terima kasih disampaikan kepada DP2M Dikti atas bantuan biaya penelitian melalui Hibah Kompetitif Strategi Nasional Tahun 2010 dengan judul Evaluasi Genetik Dan Morfologi Keturunan Populasi Hasil Seleksi Sumber Benih Sengon (Paraserianthes falcataria (L) Nielsen) Tahan Boktor (Xystrocera vestipa) Dan Produktifitas Tinggi.

\section{Daftar Pustaka}

Allard, R.W. 1992. Principles of Plant Breeding. Rev. Eds.. John Wiley and Sons, Inc. New York- London.

Chapman, H.H. and W.H. Meyer. 1949. Forest Mensuration. McGraw-Hill Book Company Inc. New York. 
Daniel, T.W., J.A. Helms, and F.S. Baker. 1992. Prinsip-prinsip Silvikultur. Gajahmada University Press. Yogyakarta. 651p.

Daradjat, A.A. 1987. Variabilitas dan Adaptasi Genotipe Terigu pada Berbagai Lingkungan Tumbuh di Indonesia. Disertasi. Universitas Padjadjaran Bandung.

Dudley, J.W. and R.N. Moll. 1969. Intertpretation and use of estimates of heritability and genetic variance in plant breeding. Crop. Sci. 9: 257-262.

Falconer, D.S. and T.F.C. Mackay. 1996. Introduction to Quantitative Genetic. Fourth Edition. Longman Group ltd. London. 464p.

Finkeldey, R. 2005. Pengantar Genetika Hutan Tropis. Djamhuri E, Siregar IZ, Siregar UJ, Kertadikara AW, penerjemah. Bogor: Fakultas Kehutanan, Institut Pertanian Bogor. Terjemahan dari: An Indtroduction to Tropical Forest Genetics.

Hardiyanto, E.B. 2000. Quantitative Genetics. Training Course on Basic Forest Genetics. Wangama-Wonogiri, 12 - 17 June 2000. Yogyakarta.

Heyne, K. 1987. Tumbuhan Berguna Indonesia. Jilid ke II cetakan ke-1. Badan LITBANG Kehutanan Jakarta. Jakarta.

Laar, A. van and Akça, A. 1997. Forest Mensuration. Cuvillier Verlag. Göttingen.

Lakitan B. 2004. Dasar-dasar Fisiologi Tumbuhan. PT RajaGrafindo Persada. Jakarta.

Lamb, D. and Borschmann, G. 1998. Agroforestry with high value trees. RIDROC publication No. 98/142.

Loveless AR. 1987. Prinsip-prinsip Biologi Tumbuhan untuk Daerah Tropika. PT Gramedia. Jakarta.

Mattjik, A.A. dan Sumertajaya M. 2000. Perancangan Percobaan dengan Aplikasi SAS dan Minitab. Jilid I. IPB Press. Bogor.

Murdaningsih, H.K., A. Baihaki, G. Satari, T. Danakusuma dan A.H. Permadi. 1990. Variasi genetik sifat-sifat tanaman bawang putih di Indonesia. Zuriat 1(1) : 32-36.
Nusifera, S. 2012. Diversitas genetik dan respon kecipir (Psophocarpus tetragonolobus L. DC) terhadap pemangkasan reproduktif. Program Pascasarjana Fakultas Pertanian Universitas Padjadjaran. Bandung.

Pinaria, A., A. Baihaki, R. Setiamihardja dan A.A. Darajat. 1995. Variabilitas genetik dan heritabilitas karakter-karakter biomassa 53 genotipe kedelai. Zuriat 6(2): 80-87.

Poehlman J. M., and Sleper D.A. 1995. Breeding Field Crops. Fourth Edition. Iowa State University Press.

Poespodarsono, S. 1988. Dasar-dasar Ilmu Pemuliaan Tanaman. Pusat Antar Universitas Institut Pertanian Bogor Bekerja Sama dengan Lembaga Sumberdaya Informasi - IPB. Bogor. Hal : $5-6$.

Rostini, N., E. Yuliani dan N. Hermiati. 2006. Heritabilitas, kemampuan genetik dan korelasi karakter daun dengan buah muda dan heritabilitas pada 21 genotip nenas. Zuriat 17(2): 114-121.

Rostini, N,. T. Herawati, N. Hermiati. M. Rachmadi, dan Murdaningsih, H.K. 2008. Pengantar Pemuliaan Tanaman. Giratuna. Bandung. 116p.

Salisbury, F.B. dan C.W. Ross. 1995. Fisiologi Tumbuhan. ITB Bandung. Bandung.

Singh, RK and BD Chaudary. 1977. Biometrical Methods in Quantitative Genetics Analysis. Kalyani Publishers. Indiana New Delhi.

Stansfield, WD. 1991. Genetika. Edisi Kedua. Terjemahan oleh Muchidin Apandi dan Lanny T. Hardy. Erlangga. Jakarta.

Sudarmadji, R. Mardjono dan H. Sudarmo. 2007. Variasi genetik, heritabilitas dan korelasi genotipik sifat-sifat penting tanaman wijen (Sesamum indicum). J. Littri 13:3. 88-92.

Van Beuningen, L.T. 1997. Genetic diversity among North American spring wheat cultivar : III Cluster analisys based on quantitative morphological traits. Crop Sci. 37 : 203-207. 